Geoheritage

\title{
THE HERITAGE INTEREST OF THE CRETACEOUS AMBER OUTCROPS IN THE IBERIAN PENINSULA, AND THEIR MANAGEMENT AND PROTECTION --Manuscript Draft--
}

\begin{tabular}{|c|c|}
\hline \multicolumn{2}{|l|}{ Manuscript Number: } \\
\hline Full Title: & $\begin{array}{l}\text { THE HERITAGE INTEREST OF THE CRETACEOUS AMBER OUTCROPS IN THE } \\
\text { IBERIAN PENINSULA, AND THEIR MANAGEMENT AND PROTECTION }\end{array}$ \\
\hline Article Type: & SI:Spanish Palaeontological Heritage \\
\hline Corresponding Author: & $\begin{array}{l}\text { Ana Rodrigo, Ph.D. } \\
\text { Instituto Geologico y Minero de Espana } \\
\text { Madrid, Madrid SPAIN }\end{array}$ \\
\hline \multicolumn{2}{|l|}{$\begin{array}{l}\text { Corresponding Author Secondary } \\
\text { Information: }\end{array}$} \\
\hline Corresponding Author's Institution: & Instituto Geologico y Minero de Espana \\
\hline \multicolumn{2}{|l|}{$\begin{array}{l}\text { Corresponding Author's Secondary } \\
\text { Institution: }\end{array}$} \\
\hline First Author: & Ana Rodrigo, Ph.D. \\
\hline \multicolumn{2}{|l|}{ First Author Secondary Information: } \\
\hline \multirow[t]{5}{*}{ Order of Authors: } & Ana Rodrigo, Ph.D. \\
\hline & Enrique Peñalver, Ph.D. \\
\hline & Rafael López del Valle, Ph.D. \\
\hline & Eduardo Barrón, Ph.D. \\
\hline & Xavier Delclòs, Ph.D. \\
\hline \multicolumn{2}{|c|}{ Order of Authors Secondary Information: } \\
\hline \multicolumn{2}{|c|}{ Funding Information: } \\
\hline Abstract: & $\begin{array}{l}\text { All the amber outcrops of the Iberian Peninsula are Lower Cretaceous in age and, in } \\
\text { the case of Spain, some of them have provided abundant and important specimens of } \\
\text { arthropods preserved as bioinclusions. These Spanish localities are rich in fossil taxa } \\
\text { of phylogenetic relevance. The evidence of both palaeoecological interactions and } \\
\text { palaeobehaviours are also abundant. Despite their high heritage interest, the actions } \\
\text { conducted to their protection and management have been very unequal. In some } \\
\text { cases, only the generic laws of national or autonomous scopes protect this heritage. } \\
\text { The purpose of the present study is to analyze the state of the art of the Iberian } \\
\text { Peninsula amber outcrops. A review of the major Cretaceous amber outcrops } \\
\text { worldwide for comparison is presented. That comparison shows, in general, that the } \\
\text { best protection, both legal and physical, occurs in Spain and that the case of Portugal } \\
\text { is very different. In addition, some actions aimed at a more effective protection and } \\
\text { management of the amber outcrops in Spain and Portugal are proposed, for example } \\
\text { the proposal to consider the outcrop of San Just, located in the Aragonese Community, } \\
\text { under a protection designation as is the so called Bien de Interés Cultural. }\end{array}$ \\
\hline Suggested Reviewers: & \\
\hline
\end{tabular}




\title{
THE HERITAGE INTEREST OF THE CRETACEOUS AMBER OUTCROPS IN THE IBERIAN PENINSULA, AND THEIR MANAGEMENT AND PROTECTION
}

\author{
A. Rodrigo ${ }^{1}$, E. Peñalver ${ }^{1}$, R. López del Valle ${ }^{2}$, E. Barrón ${ }^{1} \&$ X. Delclòs ${ }^{3}$ \\ ${ }^{1}$ Museo Geominero. Instituto Geológico y Minero de España. C/ Ríos Rosas, 23. 28003 Madrid \\ a.rodrigo@igme.es; e.penalver@igme.es; e.barron@igme.es \\ ${ }^{2}$ Museo de Ciencias Naturales de Álava-Arabako Natur Zienzien Museoa \\ C/ Siervas de Jesús, 24, 01001 Vitoria-Gasteiz. rlopezdelvalle@ araba.eus \\ ${ }^{3}$ Departament de Dinàmica de la Terra i de l'Oceà and Institut de Recerca de la Biodiversitat (IRBio), \\ Facultat de Geologia, Universitat de Barcelona, Martí i Franquès s/n, 08028 Barcelona. \\ xdelclos@ub.edu
}

\begin{abstract}
All the amber outcrops of the Iberian Peninsula are Lower Cretaceous in age and, in the case of Spain, some of them have provided abundant and important specimens of arthropods preserved as bioinclusions. These Spanish localities are rich in fossil taxa of phylogenetic relevance. The evidence of both palaeoecological interactions and palaeobehaviours are also abundant. Despite their high heritage interest, the actions conducted to their protection and management have been very unequal. In some cases, only the generic laws of national or autonomous scopes protect this heritage. The purpose of the present study is to analyze the state of the art of the Iberian Peninsula amber outcrops. A review of the major Cretaceous amber outcrops worldwide for comparison is presented. That comparison shows, in general, that the best protection, both legal and physical, occurs in Spain and that the case of Portugal is very different. In addition, some actions aimed at a more effective protection and management of the amber outcrops in Spain and Portugal are proposed, for example the proposal to consider the outcrop of San Just, located in the Aragonese Community, under a protection designation as is the so called Bien de Interés Cultural.
\end{abstract}

Keywords Palaeontological heritage, legal protection, Cretaceous amber, Konservat-Lagerstätten, type localities, Spain, Portugal.

\section{Acnowledgments}

The authors wish to thank the information on amber outcrops and protective legislation provided of their respective countries to: Dr. Dany Azar, Dr. David Grimaldi, Dr. Ryan McKellar, Dr. André Nel, Dr. George Poinar, Dr. Alex Rasnitsyn and Dr. Artur Sá. Thanks are due to Dr. Luis Carcavilla (IGME) and Juan Carlos García (DGA) for providing valuable data on legal protection of the Spanish palaeontological heritage, to Carolina Martínez Jaraiz and Eva Rodrigo for their help. This study is a contribution to project the AMBERIA (CGL2014-52163), "Iberian amber: An exceptional record of Cretaceous forests at the rise of modern terrestrial ecosystems", funded by the Spanish Ministry of Economy and Competitiveness.

\section{Introduction}

Amber is fossilized resin that was produced by a variety of vascular plants million years ago. Resin remained sticky within days or weeks, and during that period microorganisms, plant fragments, fungi and arthropods, mainly small spiders and insects, were commonly entrapped (Martínez-Delclòs et al. 2004). The amber contents of biological origin are called bioinclusions, and commonly they are preserved in exquisite detail and in their original volume, allowing fine description of the ancient taxa and, in some cases, of their ecological relationships (Martínez-Delclòs et al. 2004; Grimaldi and Engel 2005).

Amber is a significant source of information about terrestrial forest and woodland ecosystems. The large resin accumulations began during the Early Cretaceous. The concentration of large amounts of resin during the Cretaceous was consequence of copious productions in the resiniferous forests and, most likely, the event of natural catastrophes as cyclones or wildfires. Although there are hundreds of outcrops 
worldwide that provide large accumulations of amber, only a small fraction of these outcrops has important, rich fossil assemblages mainly as macroscopic biological inclusions (Martínez-Delclòs et al. 2004; Labandeira 2014). These relevant outcrops are prime candidates for special protection and management under national heritage projects. More precisely, a lot of outcrops originated during the Cretaceous period are of the major world amber deposits, but so they are as well those of the Cenozoic in the Baltic and the Caribbean regions.

Since the first reference published by Casal (1762) in his Natural and Medical History of the Principality of Asturias, more and more amber localities Cretaceous in age (practically all of them Albian in age, c. $105 \mathrm{Ma}$ ) have been found in Spain (over 120) and, to a lesser extent, in Portugal, mainly during the last two decades. However, apparently, the first author to indicate the possible presence of bioinclusions in Spanish amber was Boscá (1910) after the study of some fragments from Linares de Mora (Province of Teruel).

Similarly, the Cretaceous amber localities around the world have acquired great scientific importance in recent times, despite the fact that many of them are known since the first half of the past century. In the last two decades an intensive study of the Spanish amber has been accomplished from the stratigraphical, taphonomical, taxonomical, and palaeoecological points of view (Peñalver and Delclòs 2010). The main reason for that study was that these Spanish outcrops yielded rich collections of bioinclusions (several thousands of specimens) and many new morphotypes of organisms, many of them already described as new taxa (numerous genera and over 70 species so far (Fig. 1). For that reason, the outcrops are important type localities. The remarkable palaeobiodiversity in Spanish amber includes fungi (see Speranza et al. 2015), conifer macrorremains, pollen grains of gymnosperms (Peñalver et al. 2012, 2015), feathers, lizard skin fragments, and a lot of arthropods, mainly insects (e.g., Alonso et al. 2000; Peñalver and Grimaldi 2010; Delclòs et al. 2016; Peris et al. 2016; Sánchez-García and Engel 2016) but also includes crustaceans (e.g., Sánchez-García et al. 2015) and chelicerates (e.g., Alonso et al. 2000; Arillo et al. 2012, 2016). This amber has also yielded diverse examples of palaeoecological interactions (intra- and interspecific interactions) (e.g., Peñalver et al. 2012, 2015) and palaeobehaviours (e.g. Pérez-de la Fuente et al. 2012), showing how organisms interacted in the past, which sheds some light on the palaeobiology of the Cretaceous forests. Some of these cases correspond to the oldest known or, more remarkably, the only evidence known in the fossil record up to the present time. In addition, these geological amber sources have been crucial to understand the use of the amber by human societies in Spain, since the Paleolithic (e.g., Álvarez-Fernández et al. 2005; Peñalver et al. 2007). The scientific knowledge resulted from all these studies has been extensively popularized in the mass media, both Spanish and international media. The intensive research has been done under four successive scientific projects (CGL2005-00046/BTE,

CGL2008-00550/BTE, CGL2011-23948/BTE and CGL2014-52163), the last one of the current Spanish Minister of Economy and Competitiveness. Since 1998, the team of these projects had published over 100 articles about the Spanish amber. The two World Congresses on Amber Inclusions held in Vitoria-Gasteiz, in 1998 and 2007, and organized by the Natural Sciences Museum of Álava (Museo de Ciencias Naturales de Álava) and the Álava Provincial Council (Diputación Foral de Álava), constituted an important support for achieving research in collaboration with foreign experts. Regarding the amber outcrops in Portugal, their study has been planned and most likely during the next years some results will be published.

Despite the scientific relevance and the heritage importance of these Spanish deposits, actions aimed at their protection and management have been very unequal, relative to each other, and a minimally adequate level of protection is far from being established at the moment. A review of the heritage status and some basic proposals conducted to the improvement of the protection and management of the Spanish amber outcrops are analyzed here.

\section{Brief geological setting of the main amber outcrops}

In 1999, Peñalver et al. and Martínez-Delclòs et al. gave the novelty of the occurrence of two Early Cretaceous outcrops with amber in Sierra de Cantabria (Álava amber). This amber, which was firstly studied by a pluridisciplinary team managed from the Natural Sciences Museum of Álava, showed a high number of insect inclusions of more than twelve orders (Alonso et al. 2000). Seventeen years after, around 120 localities with Cretaceous amber have been catalogued (Peñalver and Delclòs 2010). Despite the abundance of localities, arthropod inclusions have been found only in nine of them.

The first studied outcrops were those from Sierra de Cantabria (Alonso et al. 2000; Martínez- 
Torres et al. 2011). They are located in the southern margin of the Basque-Cantabrian Basin, approximately $30 \mathrm{~km}$ south of the city of Vitoria-Gasteiz, near the village of Peñacerrada (Province of Álava) and correspond to a narrow band of outcrops of about $5 \mathrm{~km}$ long by $2 \mathrm{~km}$ wide, extending in an $\mathrm{N}$ $\mathrm{S}$ direction. The sedimentological materials of these outcrops belong to the Utrillas Group, then are upper Albian in age (Barrón et al. 2015). On the one hand, the outcrop of Peñacerrada I (currently not exposed) comprises three stratigraphic intervals (Martínez-Torres et al. 2003) constituted by (i) interbedded mudstones, sandstones and coal, (ii) coarse-grained sandstones and (iii) fine-grained sandstones covered by a heterolitic interval of mudstones. On the other hand, the outcrop of Peñacerrada II displays a variety of lithologies: sandstones, siltstones and mixed carbonates. In this part of the Basque-Cantabrian Basin, other Early Cretaceous amber outcrops occur (e.g., the outcrops of Salinillas de Buradón and the Pancorbo), but without record of bioinclusions.

Also in the Basque Cantabrian Basin, but in its north-western margin, is located the amberbearing outcrop of Rábago/El Soplao. It is included within a unit of continental to transitional marine siliciclastic deposits (Las Peñosas Formation; Najarro et al. 2010). According to own data (unpublished), the amber outcrop is upper Albian in age. The Las Peñosas Formation can be informally split into three correlatable units. The amber deposit is located in the top of the unit P2 in delta plain facies association at the so-called Rábago Section (Najarro et al. 2009). The outcrop of Rábago/El Soplao, which contains remarkable accumulations of plant remains and amber pieces, is characterized by laminated, organic clays and discontinuous beds of massive to laminated sandstones and siltstones (Najarro et al. 2009, 2010).

At the western, ambers occur in several outcrops of the Central Asturian Depression in different levels of the Ullaga Formation (upper Albian), Corao Formation (lower Cenomanian), El Caleyu Formation (lower Cenomanian), La Manjoya Formation (lower-middle Cenomanian) and the Las Tercias Formation (upper Cenomanian-middle or upper Turonian) (Arbizu et al. 1999; Peñalver and Delclòs 2010). The main amber outcrops are El Caleyu and Pola de Siero both from the Ullaga Formation. They are mainly composed by limestones, grey siltstones and silty marls with abundant marine fauna and plant remains (González-Fernández et al. 2004).

In the Iberian Range (Eastern Spain), amber has been found in more than fourteen sites. The most important outcrop in terms of amber production is San Just (Fig. 2), near to the village of Utrillas, in the Province of Teruel. It is located in the northern margin of the Aliaga Sub-basin, within the Maestrat Basin. The materials of the amber-bearing strata belong to the Escucha Formation and are middle-early part of the upper Albian on the basis of the study of ancient pollen grains of angiosperms (VillanuevaAmadoz et al. 2010). The amber of San Just has been found in grey-black claystones with abundant plant remains, overlying the upper coal levels of the Escucha Formation (Peñalver et al. 2007). More precisely, this amber deposit belongs to the Regachuelo Member, which contains several types of facies corresponding to a freshwater swamp deposit within a deltaic plain (Querol et al. 1992).

Other important amber-bearing outcrops of the Iberian Range are those of Arroyo de la Pascueta (Province of Teruel) and La Hoya (Province of Valencia). The first is located at the top of a succession of sands intercalated with grey clays and silts including abundant limonitic crusts. The upper part of the series includes some calcareous oolitic bars (Gomez et al. 2000) and a detritic and lignite-containing deposit where amber occurs (Peñalver and Martínez-Delclòs 2002). The latter outcrop is also located at the top of a succession of sand and grey clays. The amber is associated with coal deposits. Both outcrops are included in strata of the Escucha Formation of the Maestrat Basin (Peñalver and Delclòs 2010). A lower-middle Albian age has been suggested for the outcrop of Arroyo de la Pascueta y the presence of the foraminifera Mesorbitolina gr. subconcava (Gomez et al. 2000).

\section{Current heritage status of the Iberian amber outcrops}

The amber deposit of Peñacerrada II (Fig. 3) is located on one side of the road direction to the port called Ribas de Tereso (Province of Álava). Given the good preservation and scientific relevance of the biological inclusions detected in this amber since the first prospections (Martínez-Torres et al. 2011), and in order to avoid potential illegal excavations, several protective actions, suggested by the staff of the Natural Sciences Museum of Álava to the Álava Provincial Council, were developed. First, the amber outcrop was excavated using a backhoe and trucks to move the rock extracted to an abandoned quarry. In the quarry, the rock was treated mechanically, in an aqueous medium, to obtain the amber. Once this excavation concluded, the outcrop was protected with suitable materials from the site itself, mainly shales and sands. Noting that this protection was insufficient, a fence was installed. The fence is constituted by a 
metallic mesh on posts, having a wide door to allow the entry of heavy machinery for possible future excavations. In addition, an official panel reporting that the site is qualified as Heritage of Cultural Interest (BIC: Bien de Interés Cultural), and that the access is prohibited was installed. The Basque Autonomous Police was advised of the importance of this site and commissioned to visit it regularly, with the aim to prevent and detect illegal excavations done by rock collectors. Having noted the importance of the amber outcrop, the legal departments of Culture and Urban Planning of the Álava Provincial Council proceeded to the administrative process to declare it as Qualified Cultural Heritage (BCC: Bien Cultural Calificado) by the Basque Government, thus both very similar protection designations, BIC and BCC, have been assigned to this outcrop. The amber and the named Yacimiento Paleontológico de Peñacerrada/Urizaharra (Álava) were established as Monumental ensemble (Conjunto Monumental) on $30^{\text {th }}$ March, 1998. While the fence covers an area of about three hundred square meters, the legally protected area comprises four mining grids, in anticipation of the potential discovery of new amber outcrops in this geological formation. Martínez-Torres et al. (2011) published a complete review of the outcrop features in order to establish the best heritage policy for its protection and management.

The site named Peñacerrada I is located a few kilometers from Peñacerrada II and is even richer in bioinclusions (Fig. 4) (Alonso et al. 2000). This site is located on a private property and was completely covered after a first sampling that yielded many kilograms of amber for scientific study. Its peculiar status, however, provides effective protection against illegal excavations by rock collectors.

The amber deposit named Rábago/El Soplao is located approximately $80 \mathrm{~km}$ west of Santander city (Cantabria), on one side of the road leading from the Cantabrian village of Rábago to the cave of El Soplao (Fig. 5). Given the abundance and importance of the amber bioinclusions found since the first palaeontological prospections (Fig. 6), and to avoid potential illegal excavations, several actions were made. Initially, to ensure the integrity of this natural heritage, the exposed part of the outcrop was covered with a breathable fabric, while a permanent surveillance service was hired. Later, when it was observed that the result was not suitable, the breathable fabric was removed and a treated wood fence was installed taking into account the aesthetic criteria established by the heritage area named El Soplao Territory (Territorio El Soplao), which includes the amber outcrop. Subsequently, several panels informing about the protection of this "Palaeontological Outcrop" under the Cantabrian Cultural Heritage Law 11/1998, and about the forbidden access to it, were installed. However, the permanent surveillance by security guards proved too costly, so it was replaced for a system of anti-intrusion monitoring, equipped with motion sensors placed on a new fence, constituted by metallic mesh on metallic posts and installed in the interior at half meter of the existing fence. This system was completed with cameras on high poles, strategically placed to cover the entire outcrop, with the aim to send images to a security center. This equipment was installed in early 2013; however it has never worked due to the lack of a bureaucratic permit by the municipal authority up to date (2016). Similarly, since 2008, the declaration to the cave of El Soplao, which includes the amber outcrop, as BIC is blocked due to bureaucratic and/or politic reasons.

In the north of Spain, another important amber outcrop is El Caleyu (Oviedo, Asturias) (Arbizu et al. 1999), as some interesting bioinclusions have been recovered, such as the fossil holotype of the fly species Alavesia prietoi housed in the palaeontological collection of the Oviedo University. This site is located in a confined area between several expressways, which make access difficult and prevent possible illegal excavations because it is clearly visible for drivers and the police. Since the discovery of the first bioinclusions, about 20 years ago, a palaeontological excavation has been not accomplished, so it is now completely covered by vegetation making it even less accessible to both, palaeontologists and rock collectors.

The palaeontological excavations in the amber outcrop of San Just (Fig. 7) started in 2003, highlighting the importance of this outcrop due to its rich record of bioinclusions, mainly insects (Fig. 8) belonging to unknown taxa and/or to groups very scarce in the fossil record (Peñalver 2011). In addition, this outcrop provided the oldest known spider web, which demonstrated that this kind of complex structure to capture fighting insects was established during the great angiosperm diversification, a group of plants that at that time started a coevolutionary history with the pollinator insects (Peñalver et al. 2006). In regard to its heritage importance, despite the significant scientific relevance, no specific protective actions have been established, for example considering it under a special conservation status. Illegal excavations and, consequently, spoliation activities are relatively easy to undertake because the outcrop is located on the slope of a public road, and so its vulnerability is very high. Currently, the Spanish Nature Protection Service (SEPRONA) of the Civil Guard, a special police force, carries out the 
periodic surveillance of this natural site. However, as recently as April 2016 an act of spoliation was recorded in this site based on evidence of excavation in the main amber-bearing level (Luis Alcalá, pers. comm., 2016).

The amber deposit of Arroyo de la Pascueta is located in the municipality of Rubielos de Mora (Province of Teruel). It occurs at the bottom of a not well accessible ravine. Along with the lacustrine deposit of Rubielos de Mora, Lower Miocene in age, its palaeontological assemblage was musealized under the name Ambarigenous Region (Región Ambarina), one of the exhibition satellites of the Fundación Conjunto Paleontológico de Teruel- Dinópolis within the termed Dinópolis Territory (Territorio Dinópolis). One of the topics of this exhibition is the occurrence of 105 million years old amber with insects as biological inclusions which lived at the time of dinosaurs. A heritage analysis of the outcrop of Arroyo de la Pascueta was published in 2002 (Peñalver and Martínez-Delclòs 2002), including an analysis of both the potential and actual dangers that can damage this palaeontological heritage and some proposals for a better management.

The nearby outcrop of La Hoya, in Cortes de Arenoso (Province of Valencia), is very similar to the outcrop of Arroyo de la Pascueta (Peñalver and Delclòs 2010). It is rich in amber but bioinclusions are very scarce, as it was noted during a palaeontological excavation in October 2003. This site has historically been excavated by the shepherds to obtain amber and use it as incense. Its difficult access and the decline of grazing activities seem to keep it currently free of this type of non-scientific excavations.

These main outcrops, except for El Caleyu, have been excavated to obtain research collections. All the specimens found are housed in museums or other scientific institutions. The main collections are linked to the three main outcrops as Natural Sciences Museum of Álava (outcrops of Peñacerrada), Fundación Conjunto Paleontológico de Teruel- Dinópolis (outcrop of San Just) and the laboratory of the cave of El Soplao in Cantabria (outcrop of Rábago/El Soplao). These collections contain abundant type amber specimens, constituting a relevant Spanish movable heritage.

The heritage status of the Portuguese Cretaceous amber outcrops is very different. At least seven amber outcrops are known in Portugal. The first outcrops were cited by Calderón (1910), some of them dated as Jurassic, but they, most likely, could in fact be Cretaceous in age. They are poor in amber and, up to date, no bioinclusions have been found.

\section{Legislation for the palaeontological heritage protection in the Iberian Peninsula}

Palaeontological heritage in Spain was originally regarded in cultural national laws; concretely, there is a Spanish Historical Heritage Act (Law 16/1985) (LPHE: Ley de Patrimonio Histórico Español), which considers the BIC as the main protection designation for the heritage. The Autonomous Communities in which the Spanish Administration is organized, as local administrations with legislative autonomy in some aspects, makes the existence of diverse protection designations for the immovable heritage similar to that of BIC, for example, Qualified Cultural Heritage (BCC) in the Basque Country, Catalogued Heritage (Bien Catalogado) in Andalusia, and Cultural Heritage of National Interest (Bien Cultural de Interés Nacional) in Catalonia.

From the point of view of the protection of the palaeontological heritage, the LPHE includes two categories within the immovable BIC: Historic Site (Sitio Histórico) and Archaeological Zone (Zona Arqueológica). While in both cases the main criterion for protection is the palaeontological interest, this should be related to the human evolution and human activity. This linking between the palaeontological heritage and the human history/archeology is conceptually inadequate for practically all the fossil record. For this reason, some Autonomous Communities have legislated to include the legal protection of the entire palaeontological heritage. In consequence, they have proposed protection designations for their application to geological and palaeontological immovable heritages. At this respect, the so called Zona Paleontológica, broadly defined as the area in which heritage remains occur, constitutes a coherent protection designation. The Law on Natural Heritage and Biodiversity 2007 (Ley de Patrimonio Natural y Biodiversidad, 2007) has included the palaeontological heritage in the natural heritage; however, in many regions, it is still ruled by the Historical Heritage Law (Carcavilla et al. 2010).

The legal status of the Cretaceous amber outcrops mentioned is diverse and depends on the Autonomous Community in which they are located (Table 1). In the case of the Principality of Asturias, for example, there is no specific protection designation for the palaeontological heritage, but its 
legislation provided protection to the valuable heritage by enacting a decree in each case under the Regulatory Rules of the Asturian Cultural Heritage, Law 1/2001 (Normas Reguladoras del Patrimonio Cultural Asturiano, ley 1/2001).

Currently, only the amber outcrop of Peñacerrada II has protection designations, which are BIC and BCC, constituting the Site of Geological Interest (LIG: Lugar de Interés Geológico) number 129 in the inventory done by the Basque Country (Gobierno Vasco, 2011). In addition to this legal protection, the site is protected with a fence that makes it inaccessible. In comparison, the outcrop of San Just in the Aragonese Community has not a protection designation to reinforce its protection. Only the SEPRONA performs surveillance task, but it is very sporadic, thus a protocol to ensure a more efficient protection of this important site is necessary. The outcrop of Rábago/El Soplao also lacks a protection designation. Today a fence protects it and some information panels indicate that the access is prohibited, although since 2013 the installation of cameras connected to a security center, important for proper surveillance, has been interrupted.

In a similar way to Spain, in Portugal the methodology of the project Global Geosites has been established about thirty geological contexts of national and international relevance (Carcavilla et al. 2013); however, the presence on this inventory does not imply legal protection. The conservation of the palaeontological heritage, integrated into the so-called geosites (localities that constitute the geological heritage, not only the paleontological heritage, but also the related to the geomorphology, mineralogy, tectonics, stratigraphy, etc.), is explicitly recognized by the Decree Law 142/2008 that regulates the nature and biodiversity conservation. This Decree Law establishes five protection designations to apply to the geosites (National park, Wildlife park, Nature reserve, Protected landscape and Natural monument).

\section{Heritage status of the major Cretaceous amber outcrops in the world}

To compare with the Spanish heritage status of the amber outcrops, a review of the diverse protection actions accomplished by the Administrations of the main Cretaceous amber areas in the world has been made. For additional data on the amber outcrops cited in this section, except for the Russian ones, see Penney (2010).

In Canada there are two areas rich in Campanian amber, Grassy Lake in Alberta and the shores of Cedar Lake in Manitoba as secondary deposit from the former, but other minor outcrops also occur. The provinces with amber outcrops have protective legislation in place that is supposed to protect amber and other fossils (in Alberta and Saskatchewan this falls under the Historical Resources Act). Since the 1970s or 1980s, depending-on the province, fossils cannot be extracted without permission from the government: all the fossils are considered property of the Crown and are to be placed in appropriate repositories when found. Amateurs can collect amber, but under some conditions, for example they cannot sell it. Amber is also protected at the national level, since it is covered by protective legislation for archaeological artifacts. Most of the sites are fairly easy to access, but few of them produce gem-quality amber. Most of the sites in the Prairie Provinces are on leased land, thus a permission of the landowners is necessary, being all of them open, without special fences to protect them.

The most famous amber in USA is located in Sayreville (New Jersey) that yields the called Raritan amber, Turonian in age, but several other fossil localities with Cretaceous amber containing bioinclusions occur. In USA, fossils that are located in the underground of a private property belong to the owner. Thus, major laws protecting palaeontological heritage legislate exclusively on fossils found on public lands. These are the Federal Land Policy and Management Act of 1976 (FLPMA), the National Environmental Policy Act of 1969 (NEPA), and various sections of BLM's regulations found in Title 43 of the Code of Federal Regulations (CFR). The main amber outcrop is not protected and is located on private property, thus this circumstance only implies that people with excavating equipment are avoided. Years ago some people from Sayreville wanted to designate the area as "Cretaceous Park", since it contains abundant amber, leaves preserved in clays and fusainized plants from "the time of Dinosaurs". The amber outcrops in USA are not protected by fences so far. Currently, the situation is that some people collect amber without permission and some of them sell relevant pieces with bioinclusions.

In France there are important amber deposits in the region of Charentes, Cenomanian in age. In this country the majority of Laws and the principal Codes undifferentiated mineralogy and palaeontology, and are applied indistinctly. Both the Law of 10th July 1976, relative to the protection of the nature, and the Law of 2nd February 1995 (Barnier Law), relative to the protection of the environment, regulate the 
palaeontological heritage. Recently, it has been approved a new decree law on protection of sites with geological interest (Décret $n^{\circ}$ 2015-1787 du 28 décembre 2015). Localities that have a scientific interest can be named as natural reserve or geological site (any amber outcrop so far). Some of the Cretaceous amber localities are associated with opencast mines. In these cases, the Code of Mines and Quarries (Code des Mines et des Carrières) legislates the extraction, but also the Civil Code that fixed the property rights of the soil-surface and the underground, because the owner of the terrain is also the proprietary of the surface and underground up to -10 meters (Civil Code, art. 552). During the opencast-mine exploitation the owner is the responsible of the mining concession and can permit access to researchers or amateurs to collect fossils, for example in the localities of Archingeay-Les Nouillers or Puy-Puy in Charente Maritime. The amber outcrops in France are not protected by fences against illegal collection of fossils, and actually there is a certain tolerance to small-scale collection.

Lebanon is the richest country in amber outcrops (nearly 400, but only $5 \%$ yielded bioinclusions) which also are the oldest known (Barremian in age, see Maksoud et al. 2014 and Delclòs et al. 2016). Fossils and important geological sites are included in the natural heritage in Lebanon, and legally regulated. Since 1982, Law 30/82 of $14^{\text {th }}$ September 1982, the UNESCO convention about the protection of the cultural and natural heritage was ratified by the Lebanon Government. The article 15 of the decree for the regulation of the quarries, $n^{\circ} 8803$ (4/10/2002), protects all fossils found during mining extractions. The law that protects landscapes and natural sites (Law of 8th July 1939) can be used to declare new sites as protected areas. In the present time, any of the world famous Lebanon outcrops, such as Hammana or Jezzine, are protected with fences or monitoring systems.

In Myanmar is obtained one of the most important amber, the famous Burmese amber, for studying terrestrial diversity in the mid-Cretaceous. It occurs in the regions of Kachin and Magway. The Burmese amber collections in some museums and other scientific institutions along the world are of the richer ones and a lot of technical papers are published on this amber every year, mainly describing new taxa. Myanmar has not implemented laws for management and protection of the natural heritage, fossils included. In consequence, despite the abundance and importance of the Burmese amber, it is currently unprotected. After decades of isolation, the UNESCO is providing technical assistance to Myanmar in order to address conservation and restoration priorities at some cultural sites identified nearly 20 years ago, none natural. For the first time, last June the UNESCO proposed several natural areas to integral protection, but none related to palaeontology, only to wildlife. The two regions, where Cretaceous amber is found and exploited, are only protected by the people that collect and commercialize it as raw and manufactured material.

In Taimyr Peninsula, North Siberia, some of the most important Cretaceous amber deposits in the world were found, yielding abundant and important bioinclusions, mainly interesting for the palaeoentomology (Rasnitsyn and Quicke 2002). In Russia there are laws that protect both, cultural and natural heritages, and also there are laws for the exportation of pieces that can be considered of heritage interest. The exportation of collections and collectibles on mineralogy and palaeontology is restricted. In accordance with the Russian protective legislation, all the heritage objects found and described in the reports are subject to conservation in the course of any business activity, especially those associated with public works. Nevertheless, despite the existence of protective legislation, Russian Administration does not really control the palaeontological heritage. In the case of Cretaceous amber localities, such as some located in the Taimyr Peninsula, there were attempts to defend some of them at local level only and these had little real effects. In concordance with this situation, fences or monitoring systems have not been installed in the outcrops.

\section{Social impact of Spanish amber}

The protection and conservation of the palaeontological heritage are not exclusive tasks of scientists and public servants of the Administration. Citizens can and must engage in the defense of their heritage, natural heritage in this case. To engage citizens is necessary to promote diverse educational and outreach activities with their focuses on the amber as a fossil material that has been considered "a window to the past". In addition, these activities will involve an improvement of the scientific literacy of the general public.

Just as the dinosaurs irradiated a special fascination on the people, partly caused by the great impact of the Jurassic Park film and its sequels, the amber attracts a lot of people with diverse interests and knowledge: amateurs in palaeontology and gemology, nature lovers, teachers, biologists, geologists, 
school children, university students, etc. That is, the new knowledge about amber is interesting for a wide range of scientists and the general public, which can be explained by the exceptionally well preserved fossils in its interior and the beauty and the diverse uses associated to the amber.

Aware of this fact, so far we have carried out numerous actions to popularize the amber, mainly focused on the Cretaceous Spanish amber and the scientific research done so far. Below we highlight some of these didactic approaches, which obtained a high broadcasting, categorized according to the format used:

1) Exhibitions.

a. The permanent exhibition of the Natural Sciences Museum of Álava entitled "Cretaceous Planet" (Planeta Cretácico), with a large selection of amber specimens from diverse localities with special attention to the amber of Peñacerrada (Fig. 9).

b. The traveling exhibition entitled "The long journey of the El Soplao amber" (El largo viaje del ámbar de El Soplao), produced by the Regional Society of Cantabrian Tourism (Sociedad Regional de Turismo de Cantabria) and exhibited in Spain during the years 2010 and 2011; it showed different types of fossil resins, and stromatolites, fossil plants and selected fossil arthropods of all geological periods from the Precambrian to the Holocene, as well.

c. The traveling exhibition entitled "Insects in amber: caught in time" (Insectos en ámbar: atrapados en el tiempo), made and produced by the Geominero Museum of the Geological Survey of Spain (IGME); it showed selected pieces of Baltic and Dominican ambers, containing exceptional palaeobiological fossils, and large pieces of copal, a type of younger fossil resin (Fig. 10). It was exhibited in Spain for three years in science institutions, universities and museums.

2) Audiovisuals.

The audiovisual entitled "Gea and the amber" (Gea y el ámbar), from the series of documentaries named Gea and created by the IGME, won the first prize Ciencia en Acción 2011 as the best didactic audiovisual of science. It shows a tour through the major amber sites in Spain explaining what the amber is and how it originated, presenting its palaeobiological content, and its heritage importance and scientific relevance for the palaeontological research. It has been distributed for free in DVD format to Spanish schools and currently it has more than 500,000 downloads from the web

(http://www.igme.es/ZonaInfantil/Mascotas/GeaAmbar.htm). It is available in Spanish and English.

3) Comic book.

As a result of the collaboration between the IGME, the University of Barcelona, the Senckenberg Museum in Frankfurt and National Geographic Society a comic book entitled Vongy: an adventure among scientists has been recently published (Fig. 11). This story is specifically aimed to children and illustrates the process of resin trapping and the natural dispersion of species through an adventure of discovery and dangerous journey across the ocean. It resulted from the experience of some members of the research team during a research stay in Madagascar. The comic book has been published in English, French, German and Spanish, and it is distributed for free and also available in pdf format (www.senckenberg.de/vongy).

4) Congresses.

a. From 20 to 23 October 1998, The World Congress on Amber Inclusions was held in Vitoria-Gasteiz city (Álava, Spain). It was organized by the Department of Culture and Euskera of the Álava Provincial Council. More than one hundred amber experts from fourteen countries gathered in Vitoria-Gasteiz to discuss the state of the art of the multidisciplinary amber research.

b. From 4 to 9 May 2007 three meetings in one under the name of Fossilsx 3 met numerous researchers also in Vitoria-Gasteiz city: the IV International Congress of Palaeoentomology, the III World Congress on Amber Inclusions, and III International Meeting on Continental Paleoarthropodology. This multi-meeting was organized by the Department of Culture, Youth and Sport of the Álava Provincial Council.

5) Conferences.

During the last decade, members of the amber research team have given numerous conferences about the amber bioinclusions, the Spanish deposits, the gemological importance of the amber, the suitable techniques to prepare and preserve amber, etc.

6) Mass media. 
Many of the results obtained after ca. two decades of research in amber (discovery of new taxa, palaeobiological and palaeoecological reconstructions, phylogenetic relationships, etc.) have been disseminated in the mass media obtaining a high broadcasting, both in national and international mass media. Some selected reports are those published in Spanish weekly journals (El País and El Mundo), tv interviews in Canal Satélite Digital and Antena 3, and the short reports published by National Geographic Magazine in its Spanish version.

\section{Discussion}

The majority of countries, where the major Cretaceous amber deposits exist, have laws to protect the palaeontological heritage (depending on these countries fossils are included as a part of the Natural Heritage or the Cultural Heritage), but it is important to note that presently the Administrations of all these countries pay little attention, or none, to the protection of their palaeontological heritage. It contrasts with Spain, where fossils are considered under the Cultural Heritage, private collecting is not permitted, and local authorities in general are very active in the protection of the amber outcrops, which includes the installation of fences as in the localities of Peñacerrada II and Rábago/El Soplao. In some foreign countries, effective protection comes from the fact that some important amber outcrops are located in private properties or in active quarries, implicating a protection by the own owners. Also, it appears that the local Administrations are the more efficient, if is the case, respect to something like a protective policy. In some countries, the illegal small-scale excavation implies that part of the amber is sold, except to the case of Myanmar where practically all the amber extracted is exported as gemological raw, manufactured material or amber with bioinclusions. In contrast, currently in Spain the amber only can be excavated under scientific projects, done by qualified researchers who must house all the specimens found in public scientific institutions. However, in the past, a few anecdotic cases of commercial amber exploitation were reported, as were the exportation of amber from the Utrillas-Valdeconejos coal area in the Province of Teruel (De Aldana 1863), and the small-scale amber mining near Moratalla village in the Province of Murcia (González Carvajal, 1832; see also Peñalver et al. 2013) and at Vilada and San Vicente de Castell d'Arenys area in the Province of Barcelona since 1880 (DGAIC 1882).

All fossils that are found in the subsoil from public and private lands belong to the public Spanish Heritage, and are protected by cultural heritage laws, without exceptions. In Spain, the legal status of the palaeontological heritage is similar to that in Canada, where the degree of protection of the amber outcrops depends on the different provinces (in Spain it depends on the different Autonomous Communities); for example Ontario is one of the less restrictive Canadian provinces, but in Alberta the Historical Resources Act prohibits removal of fossils from the province without a Disposition Certificate issued by the Government of Alberta, nevertheless, the act of collecting a fossil that requires no use of tools can be picked up freely.

In Spain, the scientific, cultural and/or educative value of the geological heritage is recognized by the Law 33/2015, amending the Law 42/2007 of the Natural Heritage and Biodiversity. Also in its Annex VIII concerning the "Geodiversity of the Spanish territory" (Geodiversidad del territorio español), it considers the "Fossils and ichnofossils of the continental Mesozoic of the Iberian Peninsula" (Fósiles $e$ icnofósiles del Mesozoico continental de la Península Ibérica) as one of the Spanish geological contexts of global relevance. On a smaller scale, the outcrops of Peñacerrada, San Just, Arroyo de la Pascueta and El Caleyu were catalogued as Spanish Geosites of international relevance (Carcavilla and Palacio 2010). The site of Rábago/El Soplao, in turn, was discovered later.

The Spanish protective legal framework recognizes the scientific importance of the Cretaceous palaeontological sites. The need for their conservation entails the convenience of protection designations provided by the Spanish Administration, which implies a reinforced legal status to this valuable fossil record, better preserving it against potential damages. Since the Autonomous Communities set protection designations for the most important sites, including those with geological and palaeontological interest, it is a priority the impulse of the administrative processes together with the autonomous institutions related to the heritage; for example, the amber outcrop of San Just could be considered as BIC, concretely the modality termed Palaeontological Zone (Zona Paleontológica). It would also be desirable to impulse together with the Cantabrian Administration the process for considering La Cueva de El Soplao, and the amber deposit related to it, as BIC, a protection designation that is paralyzed in this case since 2008. 
Finally, the use of local amber by human societies in Spain, since the Paleolithic, implicates that this fossil plant material and the Spanish outcrops also have cultural value; together with the scientific value (some of the outcrop are type localities, contain diverse types of fossils and palaeobiological evidence, etc.), it increases their heritage interest, important for a correct heritage evaluation and management.

\section{Conclusions}

Spain can be regarded as a leading country on what concerns the protection of the Cretaceous amber outcrops. In fact, the protective legislation in Spain for the palaeontological heritage, although variable in some aspects depending of the Autonomous Communities, is very restrictive, also for granting permits for scientific study. This results, for example, in the complete absence of Spanish amber illegal commercialization, with or without bioinclusions. This suitable situation largely stems from nearly two decades of uninterrupted research on Spanish amber by a multidisciplinary national team with the collaboration of international experts. The results have been not only scientists, or related to the knowledge and protection of this heritage, but also an increase of the scientific literacy and the social interest on the palaeontological heritage. However, much remains to be done. In our opinion, two actions are considered priority: 1) the outcrop of Rábago/El Soplao must get finally a protection designation (BIC), now pending although paralyzed, and the activation of the system of motion detection and alarm installed some years ago, and 2) to initiate the administrative process to declare the outcrop of San Just as BIC, in collaboration with various Aragonese institutions such as the Fundación Conjunto Paleontológico de Teruel-Dinópolis, the Utrillas City Hall and the General Council of Aragon (DGA: Diputación General de Aragón). This may not involve a public financial allowance for their protection, or simply the installation of a protective fence, at least in the short term, but will certainly help to give recognition at national level and to increase the local protection and interest of the citizens of the village of Utrillas, for example including a more intense surveillance by the SEPRONA.

In Portugal, the amber outcrops could be considered under the protection designation called Natural monument, according to the Decree Law 142/2008. This protection designation is defined for a locality that should be conserved due to its uniqueness or rarity, or for its aesthetic, scientific or cultural singularity. According to the current data about the amber deposits in this country, seems clear that the systematic study of the whole Portuguese amber outcrops will involve the declaration of some of them as Natural monuments.

\section{References}

Alonso J, Arillo A, Barrón E, Corral JC, Grimalt J, López JF, López R, Martínez-Delclòs X, Ortuño V, Peñalver E, Trincão PR (2000) A new fossil resin with biological inclusions in Lower Cretaceous deposits from Álava (Northern Spain, Basque-Cantabrian Basin). Journal of Paleontology 74:158-178.

Álvarez-Fernández E, Peñalver E, Delclòs, X (2005) La presencia de ámbar en los yacimientos prehistóricos (del Paleolítico superior a la Edad de Bronce) de la Cornisa Cantábrica y sus fuentes de aprovisionamiento. Zephyrus 58:159-182.

Arbizu M, Bernárdez E, Peñalver E, Prieto MA (1999) El ámbar de Asturias (España). Estudios Museo Ciencias Naturales de Álava 14 ( $\mathrm{n}^{\circ}$ especial 2):245-254.

Arillo A, Subías LS, Sánchez-García A (2016) New species of fossil oribatid mites (Acariformes, Oribatida), from the Lower Cretaceous amber of Spain. Cretaceous Research 63:68-76.

Arillo A, Subias LS, Shtanchaeva U (2012) A new species of fossil oribatid mite (Acariformes, Oribatida, Trhypochthoniidae) from the Lower Cretaceous amber of San Just (Teruel Province, Spain). Systematic \& Applied Acarology 17:106-112.

Barrón E, Peyrot D, Rodríguez-López JP, Meléndez N, López del Valle R, Najarro M, Rosales I, ComasRengifo MJ (2015) Palynology of Aptian and upper Albian (Lower Cretaceous) amber-bearing outcrops of the southern margin of the Basque-Cantabrian basin (northern Spain). Cretaceous Research 52:292-312.

Boscá A (1910) Cuenca calaminífera de Linares de Aragón. Asociación Española Progreso Científico 4:171-181.

Calderón S (1910) Los minerales de España. Junta para Ampliación de Estudios e Investigaciones Científicas. Madrid, Imprenta Eduardo Arias. 2 tomos, $416+561$ pp. Reedición facsímil.

Carcavilla L, Díaz-Martínez, E, Erikstad, L, García-Cortés, Á (2013) Valoración del patrimonio geológico en Europa. Boletim Paranaense de Geociências, 70:28-40. 
Carcavilla L, Durán JJ, García-Cortés, A, López-Martínez, J (2010) Geological heritage and geoconservation in Spain: past, present and future. Geoheritage 1 (2):75-91.

Carcavilla, L, Palacio, J (2010). Proyecto Geosites. Aportación española al patrimonio geológico mundial. Instituto Geológico y Minero de España. Madrid. 231 pp.

Casal G (1762) Succini Asturici, à Doctore Gafpar Cafal, Almae Eclefiae Cathedralis Ovetenfis Medico, reperti, folertique ejufdem cura probati, \& examinati, Hiftoria. Historia Natural y Médica del Principado de Asturias, Ed. Facsímil 1998. Servicio de Publicaciones. Principado de Asturias, Oviedo. 764 pp.

De Aldana L (1863) Sobre los depósitos carboníferos de Utrillas y Gargallo (Conclusión). Revista Minera 14 (313):293-300.

Delclòs X, Peñalver E, Arillo A, Engel MS, Nel A, Azar D, Ross A (2016) New mantises (Insecta: Mantodea) in Cretaceous ambers from Lebanon, Spain and Myanmar. Cretaceous Research 60: 91-108.

DGAIC (1882) Estadística Minera de España, correspondiente al año de 1879. Estadística Minera. Ministerio de Fomento, Dirección General de Agricultura, Industria y Comercio. 61 pp + 7 láminas.

Gobierno Vasco (2011). Departamento de Medio Ambiente y Política Territorial. http://www.ingurumena.ejgv.euskadi.eus/r49u95/es/contenidos/informacion/lig/es_def/adjuntos/129.pdf. Accessed 20 September 2016.

Gomez B, Martín-Closas C, Barale G, Thévenard F (2000) A new species of Nehvizdya (Ginkgoales) from the Lower Cretaceous of the Iberian Range (Spain). Review of Palaeobotany and Palynology 111:49-70.

González Carvajal T (1832) Registro y relación general de las minas de la Corona de Castilla: Primera Parte. Comprende los registros, relaciones y despachos tocantes á minas, en que se expresan los pueblos y sitios en que se hallaron. Por Don Miguel de Burgos, Tomo I. Madrid. 718 pp.

González-Fernández B, Menéndez-Casares E, Gutiérrez-Claverol M, García-Ramos JC (2004) Litoestratigrafía del sector occidental de la cuenca cretácica de Asturias. Trabajos de Geología de la Universidad de Oviedo 24:43-80.

Grimaldi DA, Engel MS (2005) Evolution of the Insects. Cambridge University Press, New York. 772 pp.

Labandeira CC (2014) Amber. In: Reading and Writing of the Fossil Record: Preservational Pathways to Exceptional Fossilization. The Paleontological Society Papers, vol. 20. Marc Laflamme, James D. Schiffbauer, and Simon A.F. Darroch (Eds.), The Paleontological Society Short Course:163217.

Maksoud S, Granier B, Azar D, Geze R, Paicheler J-C, Moreno-Bedmar JA (2014) Revision of "Falaise de BLANCHE" (Lower Cretaceous) in Lebanon, with the definition of a Jezzinian Regional Stage. Carnets de Géologie 14:401-427.

Martínez-Delclòs X, Arillo A, Ortuño V, Peñalver E (1999) El ámbar del Cretácico Inferior de Peñacerrada (Álava, España). Temas Geológico-Mineros 26:13-17.

Martínez-Delclòs X, Briggs DEG, Peñalver E (2004) Taphonomy of insects in carbonates and amber. Palaeogeogaph,, Palaeoclimatoogy, Palaeoecology 203:19-64.

Martínez-Torres LM, Alonso J, Valle JM (2011) The upper Aptian-lower Albian amber deposit of the Peñacerrada II Geosite (Basque-Cantabrian basin, Northern Spain): geological context and protection. Geoheritage 3:55-61.

Martínez-Torres LM, Pujalte V, Robles S (2003) Los yacimientos de ámbar de Montoria-Peñacerrada (Álava, Cuenca Vasco-Cantábrica): estratigrafía, reconstrucción paleogeográfica y estructura tectónica. Estudios Museo Ciencias Naturales Álava 18:9-32.

Najarro M, Peñalver E, Pérez-de la Fuente R, Ortega-Blanco J, Menor-Salván C, Barrón E, Soriano C, Rosales I, López del Valle R, Velasco F, Tornos F, Daviero-Gomez V, Gomez B, Delclòs X (2010) Review of the El Soplao amber outcrop, Early Cretaceous of Cantabria, Spain. Acta Geologica Sinica (English Ed) 84:959-976.

Najarro M, Peñalver E, Rosales I, Pérez-de la Fuente R, Daviero-Gomez V, Gomez B, Delclòs X (2009) Unusual concentration of Early Albian arthropod-bearing amber in the Basque-Cantabrian Basin (El Soplao, Cantabria, Northern Spain): Palaeoenvironmental and palaeobiological implications. Geologica Acta 7:363-387.

Penney, D (2010) Biodiversity of fossils in amber from the major world deposits. Siri Scientific Press, Manchester. 303 pp.

Peñalver E, Delclòs X (2010) Spanish amber. In: Penney D (ed.) Biodiversity of fossils in amber from the major world deposits. Siri Scientific Press, Manchester:236-270. 
Peñalver E, Grimaldi DA (2010) Latest occurrences of the Mesozoic family Elcanidae (Insecta: Orthoptera), in Cretaceous amber from Myanmar and Spain. Annales de la Société Entomologique de France 46:88-99.

Peñalver E, Martínez-Delclòs X (2002) Importancia patrimonial de Arroyo de la Pascueta, un yacimiento de ámbar cretácico con insectos fósiles en Rubielos de Mora. In: Meléndez-Hevia G, Peñalver E (eds) El patrimonio paleontológico de Teruel. Instituto de Estudios Turolenses:201-208.

Peñalver E, Álvarez-Fernández E, Arias P, Delclòs X, Ontañón R (2007) Local amber in a Palaeolithic Context in Cantabrian Spain: the case of La Garma A. Journal of Archaeological Science 34: 843-849.

Peñalver E, Arillo A, Riccio ML, Pérez-de la Fuente R, Delclòs X, Barrón E, Grimaldi DA (2015) Longproboscid Flies as Pollinators of Cretaceous Gymnosperms. Current Biology 25 (14):1917-1923.

Peñalver E, Delclòs X, Soriano C (2007) A new rich amber outcrop with palaeobiological inclusions in the lower Cretaceous of Spain. Cretaceous Research 28:791-802.

Peñalver, E, Grimaldi, D, Delclòs, X (2006) Early Cretaceous Spider Web with Its Prey. Science, 312 : 1761.

Peñalver E, Labandeira CC, Barrón E, Delclòs X, Nel P, Nel A, Tafforeau P, Soriano, C (2012) Thrips Pollination of Mesozoic Gymnosperms. Proceedings of the National Academy of Sciences 109 (22):8623-8628.

Peñalver E, Martínez-Delclòs X, Arillo A (1999) Yacimientos con insectos fósiles en España. Revista Española de Paleontología, 14:231-245.

Peñalver E, Tent Manclús JE, Romero Sánchez G, Sobrado Calvo C., Rodríguez Sánchez J (2013) Rediscovery of the Moratalla amber (Murcia, Spain): a Cretaceous outcrop in the southernmost end of the peninsular amber strip. Macla 17:85-86.

Peñalver Mollá, E (2011) Ámbar cretácico de San Just (Teruel): los insectos que convivieron con los dinosaurios. Isurus, 4:24-36.

Pérez-de la Fuente R, Delclòs X, Peñalver E, Speranza M, Wierzchos J, Ascaso C, Engel MS (2012) Early evolution and ecology of camouflage in insects. Proceedings of the National Academy of Sciences, 190 (52): 21414-21419.

Peris D, Ruzzier E, Perrichot V, Delclòs X (2016) Evolutionary and paleobiological implications of Coleoptera (Insecta) from Tethyan-influenced Cretaceous ambers. Geoscience Frontiers 7:695706.

Querol X, Salas R, Pardo G, Ardevol L (1992) Albian coal-bearing deposits of the Iberian Range in northeastern Spain. In: McCabe PJ, Parrish JT (eds) Controls on the distribution and quality of Cretaceous coals. Geological Society of America Special Paper 267:193-208.

Rasnitsyn AP, Quicke DLJ (Eds.) (2002) History of Insects. Kluwer Academic Publishers. 517 pp.

Sánchez-García A, Engel MS (2016) Long-term stasis in a diverse fauna of Early Cretaceous springtails (Collembola: Symphypleona). Journal of Systematic Palaeontology, 15 (7): 513-537.

Sánchez-García A, Peñalver E, Pérez-de la Fuente R, Delclòs X (2015) A rich and diverse tanaidomorphan (Crustacea: Tanaidacea) assemblage associated with Early Cretaceous resinproducing forests in North Iberia: palaeobiological implications. Journal of Systematic Palaeontology 13 (8):645-676.

Speranza M, Ascaso C, Delclòs X, Peñalver E (2015) Cretaceous mycelia preserving fungal polysaccharides: Taphonomic and paleoecological potential of microorganisms preserved in fossil resins. Geologica Acta 13:409-431.

Villanueva-Amadoz U, Pons D, Díez JB, Ferrer J, Sender LM (2010) Angiosperm pollen grains of San Just site (Escucha Formation) from the Albian of the Iberian Range (north-eastern Spain). Review of Palaeobotany and Palynology 162:362-381.

\section{Figure captions}

Figure 1. Cantabroraphidia marcanoi, a genus and species of the rare extinct family Mesoraphidiidae described from the amber of Rábago/El Soplao. Graphic scale $=1 \mathrm{~mm}$.

Figure 2. Amber piece found during a palaeontological excavation at the outcrop of San Just.

Figure 3. Amber deposit of Peñacerrada II, in the Province of Álava, protected with a fence and showing an official panel reporting its heritage status. 
Figure 4.Specimen of the order Pseudoscorpiones, an uncommon chelicerate group in the fossil record, from the amber outcrop of Peñacerrada I. Body length ca. $1.5 \mathrm{~mm}$.

Figure 5. The amber deposit of Rábago/El Soplao, in Cantabria, was physically protected with two fences and a system with motion sensors, but complete implementation is stopped since some years.

Figure 6. Detail of an amber piece of Rábago/El Soplao containing a rich assemblage of arthropods, mainly insects. Scale graphic $=1 \mathrm{~mm}$.

Figure 7. Amber deposit of San Just, in the Province of Teruel, has not physical protection. This picture shows the stratigraphic section in front of the classical section, also rich in amber.

Figure 8. Wasp of the family Scelionidae from the outcrop of San Just showing the exceptional preservation of the bioinclusions in the Spanish amber. Body length ca. $2 \mathrm{~mm}$.

Figure 9. Detail of the permanent amber exhibition, mainly of Cretaceous Spanish amber, in the Natural Sciences Museum of Álava.

Figure 10. Exhibition information on the exhibition titled in English "Insects in amber: caught in time" created by the IGME and inaugurated in 2007.

Figure 11. Cover of a comic book (English version) on the amber study, resin taphonomy and species dispersion, published in 2016. 
Table 1 Protection designations of the Spanish historic and cultural heritages to apply to the geological heritage of immovable palaeontological interest, of the Autonomous Communities (CCAA) where the main Cretaceous amber outcrops occur.

\begin{tabular}{|c|c|c|c|}
\hline CCAA & Outcrops & $\begin{array}{c}\text { Main protection } \\
\text { designation }\end{array}$ & $\begin{array}{c}\text { Protection designations to apply to the Immovable } \\
\text { Palaeontological Heritage }\end{array}$ \\
\hline \multirow[t]{2}{*}{ Aragon } & \multirow{2}{*}{$\begin{array}{l}\text { Arroyo de la } \\
\text { Pascueta } \\
\text { San Just }\end{array}$} & \multirow[t]{2}{*}{$\begin{array}{l}\text { BIC (Heritage of } \\
\text { Cultural Interest - Bien } \\
\text { de Interés Cultural) }\end{array}$} & $\begin{array}{l}\text { Archaeological Zone (Zona Arqueológica) } \\
\text { Palaeontological Zone (Zona Paleontológica) }\end{array}$ \\
\hline & & & Cultural Park (Parque Cultural) \\
\hline \multirow[b]{2}{*}{$\begin{array}{l}\text { Principality } \\
\text { of Asturias }\end{array}$} & \multirow[b]{2}{*}{ El Caleyu } & $\mathrm{BIC}$ & Archaeological Zone (Zona Arqueológica) \\
\hline & & & $\begin{array}{l}\text { Archaeological Area (Espacio Arqueológico) } \\
\text { Geological and palaeontological heritage protection via Decree (Law } \\
1 / 2001 \text { of } 6 \text { March. Seventh Additional Provision) [Protección } \\
\text { patrimonio geológico y paleontológico vía Decreto (Ley 1/2001, de } 6 \\
\text { de marzo. Disposición adicional Séptima)] }\end{array}$ \\
\hline \multirow[t]{2}{*}{ Cantabria } & \multirow[t]{2}{*}{$\begin{array}{l}\text { Rábago/El } \\
\text { Soplao }\end{array}$} & $\mathrm{BIC}$ & $\begin{array}{l}\text { Monument (Monumento) } \\
\text { Archaeological Zone (Zona Arqueológica) }\end{array}$ \\
\hline & & & $\begin{array}{l}\text { Archaeological outcrop (Yacimiento Arqueológico) } \\
\text { Archaeological Park (Parque Arqueológico) } \\
\text { Area of Archaeological Protection (Área de Protección Arqueológica) }\end{array}$ \\
\hline \multirow{2}{*}{$\begin{array}{l}\text { Basque } \\
\text { Country }\end{array}$} & \multirow{2}{*}{$\begin{array}{l}\text { Peñacerrada I } \\
\text { Peñacerrada II }\end{array}$} & $\begin{array}{l}\text { BCC (Qualified Cultural } \\
\text { Heritage - Bien Cultural } \\
\text { Calificado) }\end{array}$ & $\begin{array}{l}\text { Monument (archaeological zone) [Monumento (zona arqueológica)] } \\
\text { Monumental ensemble (archaeological zones) [Conjunto Monumental } \\
\text { (zonas arqueológicas)] }\end{array}$ \\
\hline & & & $\begin{array}{l}\text { Areas of archaeological presumption (Zonas de presunción } \\
\text { arqueológica) }\end{array}$ \\
\hline $\begin{array}{l}\text { Valencian } \\
\text { Community }\end{array}$ & La Hoya & $\mathrm{BIC}$ & $\begin{array}{l}\text { Archaeological Zone (Zona Arqueológica) } \\
\text { Palaeontological Zone (Zona Paleontológica) }\end{array}$ \\
\hline
\end{tabular}




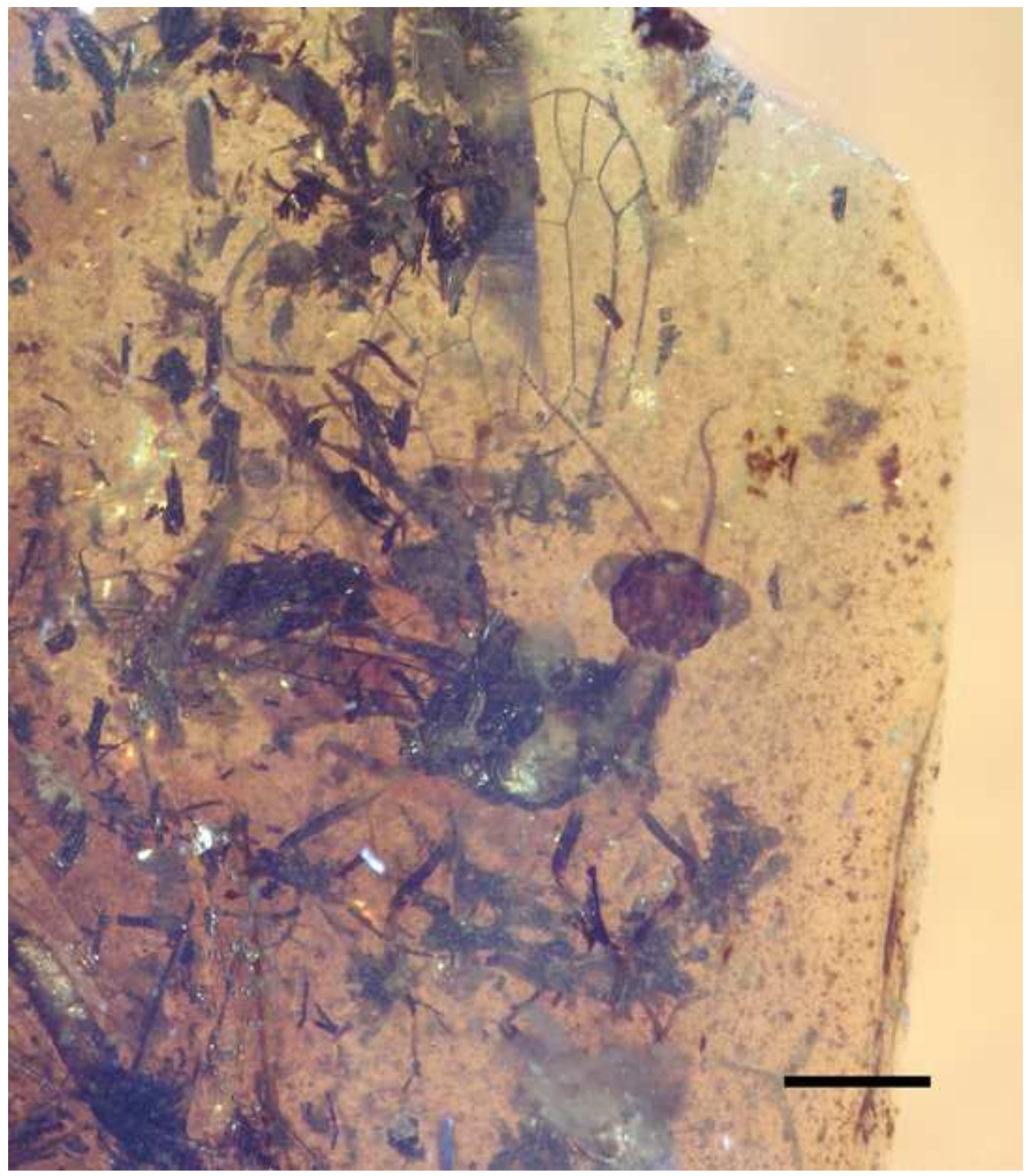




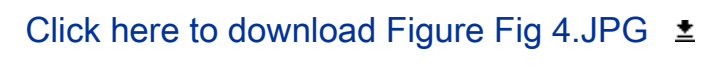
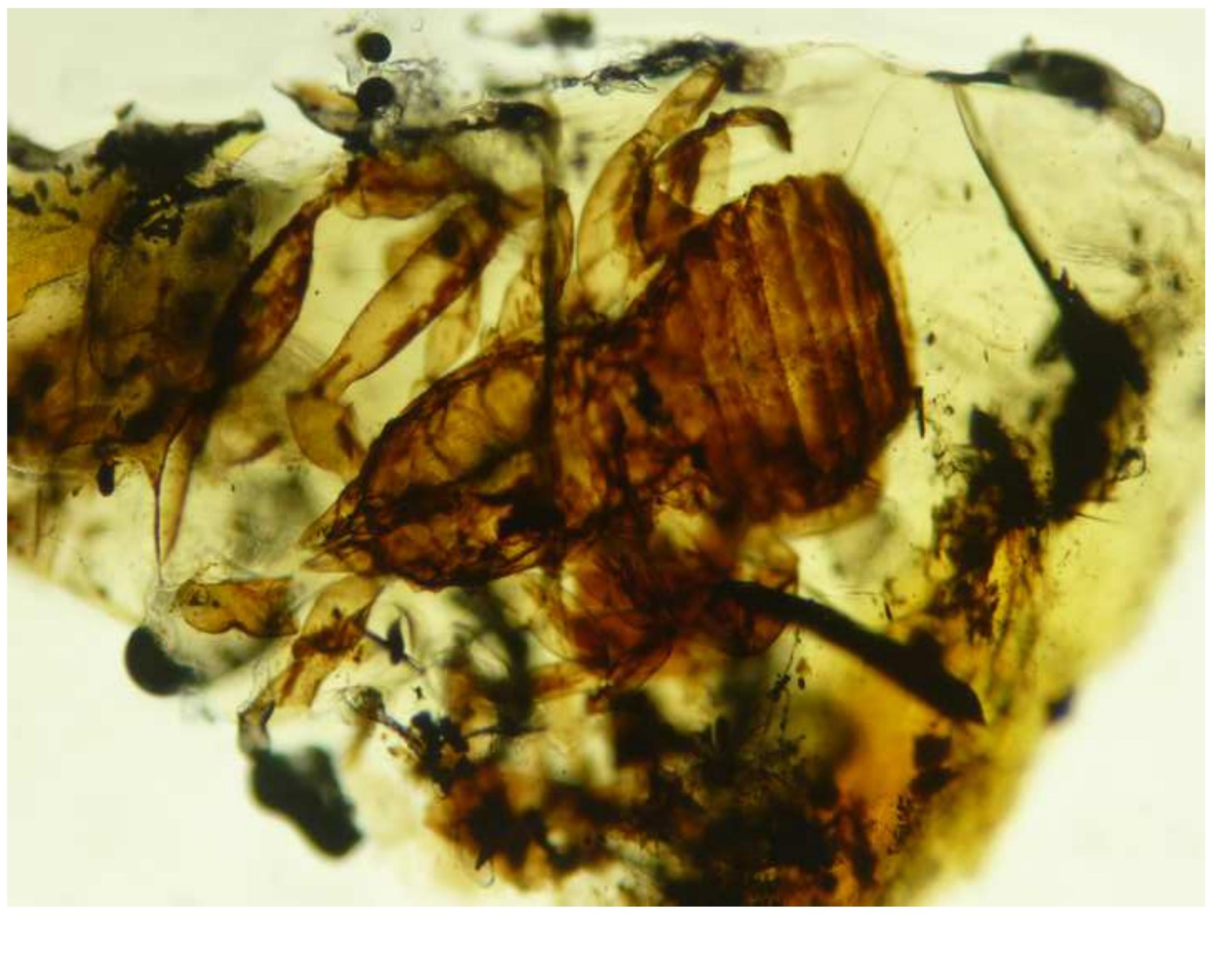


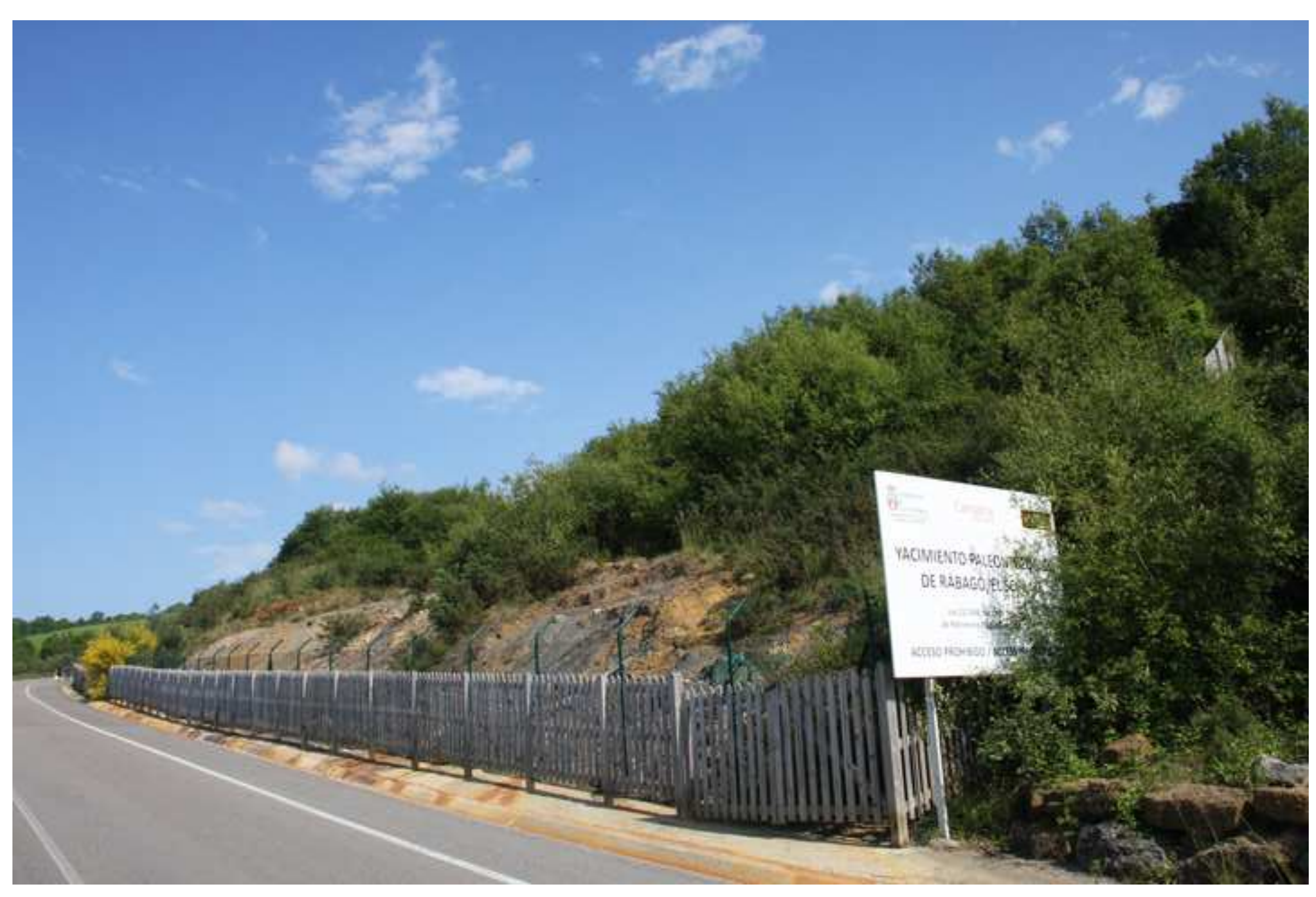


Click here to download Figure Fig 6.jpg $\underline{\underline{\Perp}}$
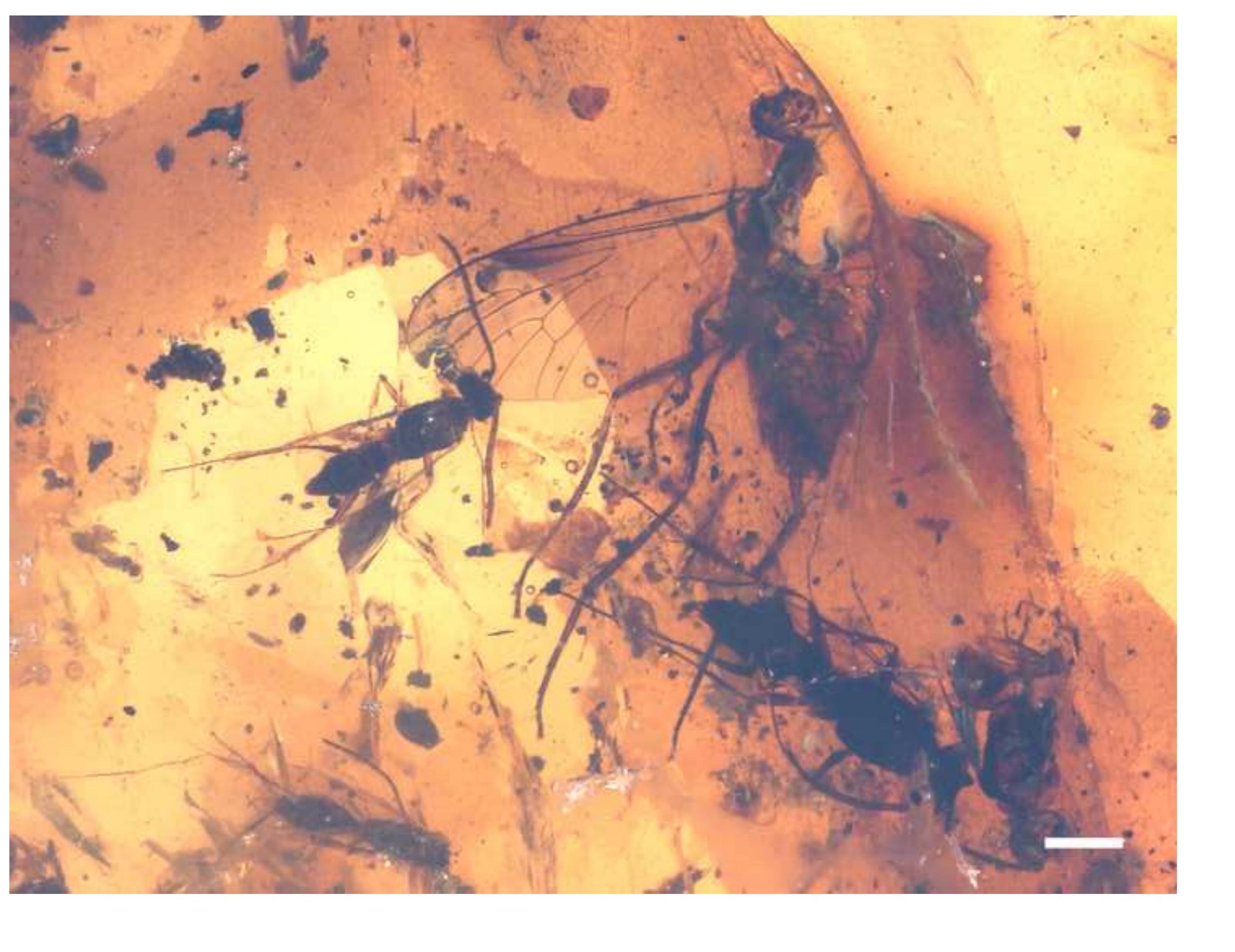


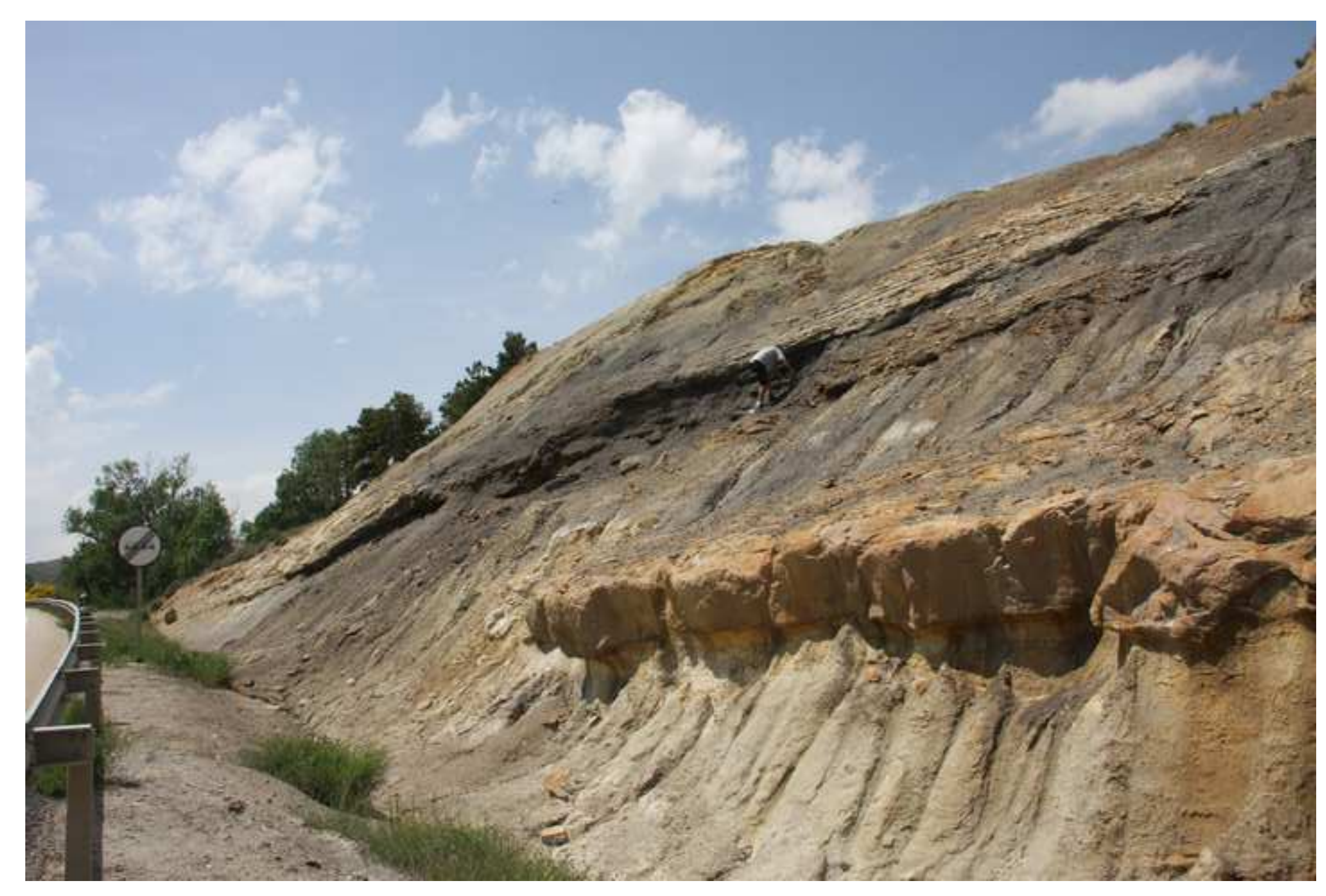




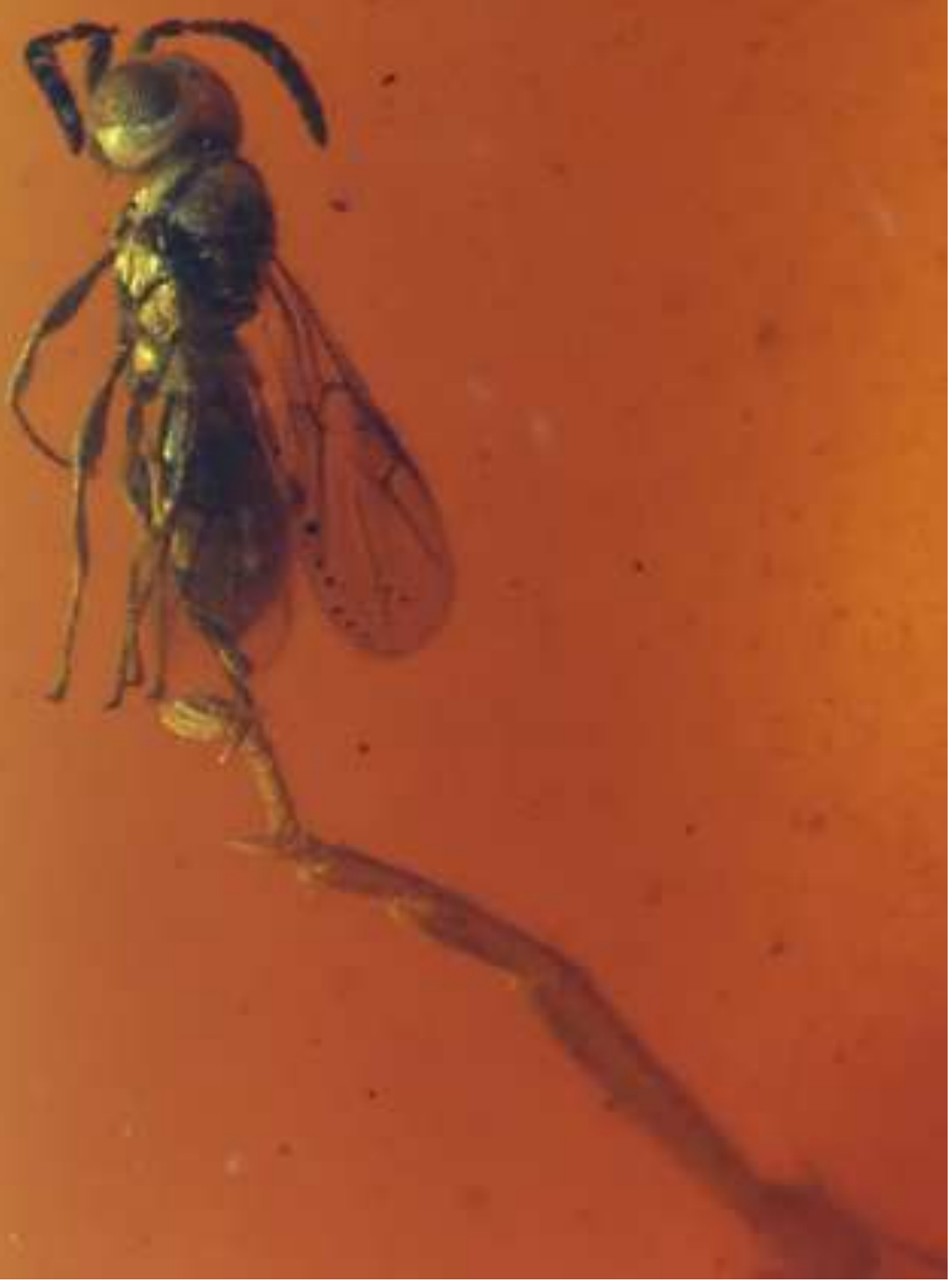




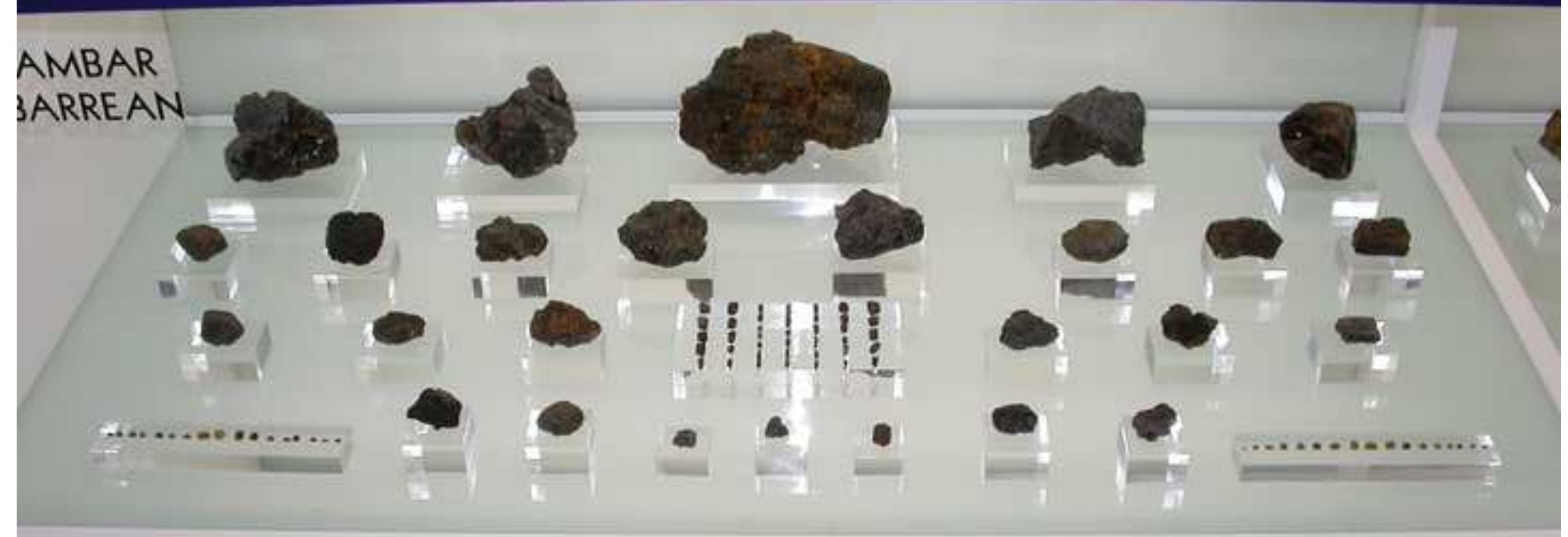




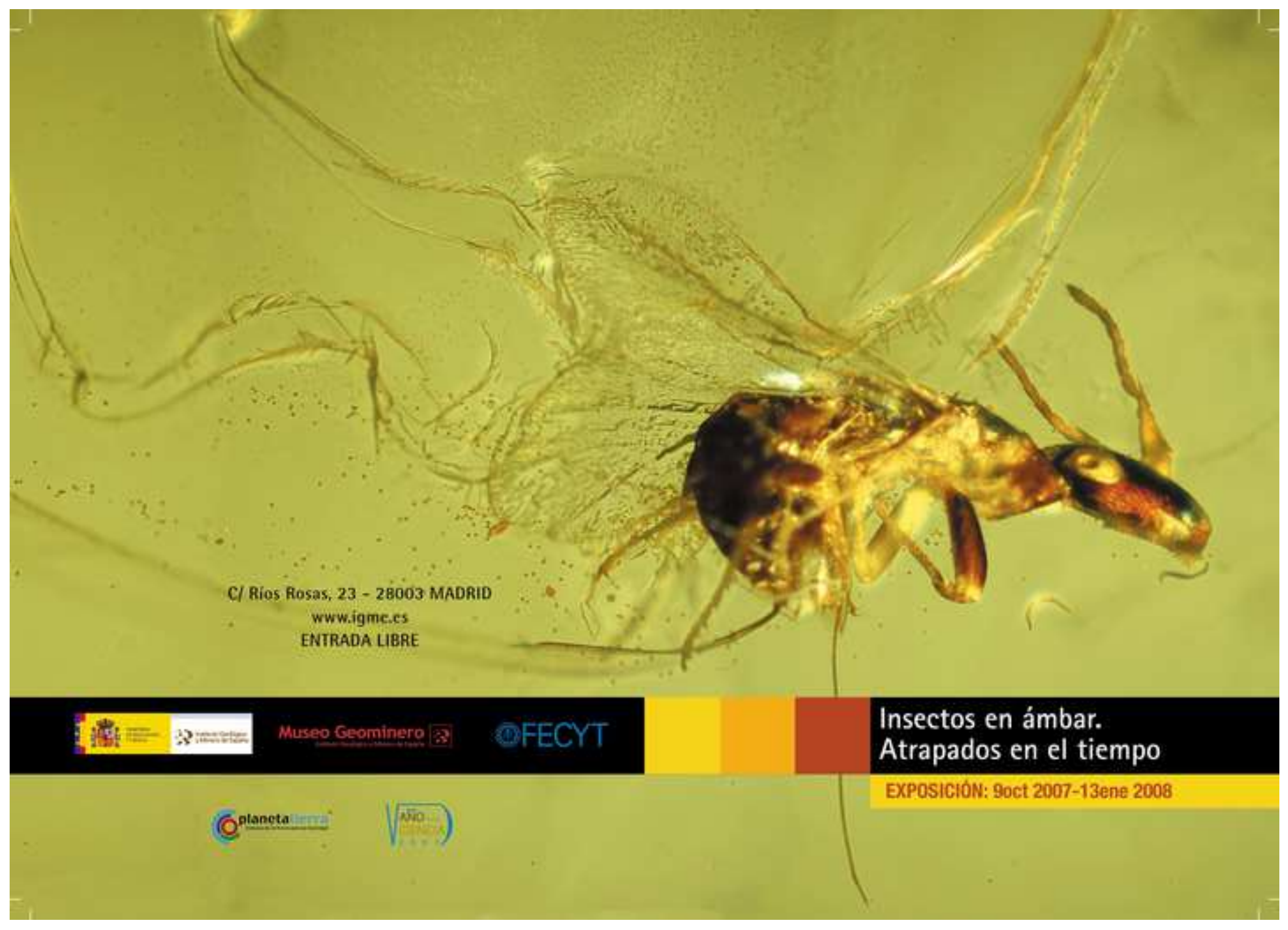



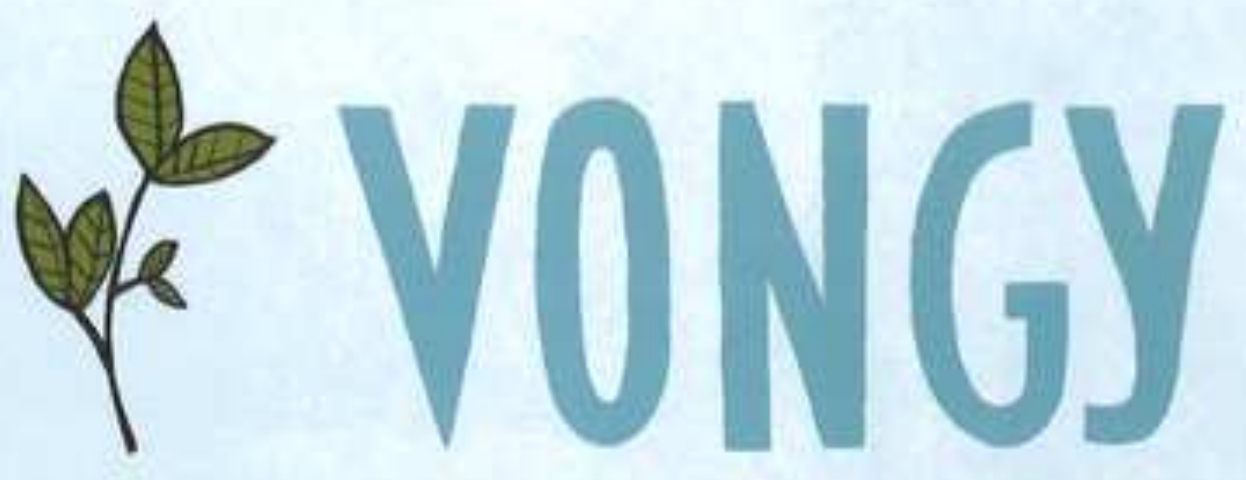

An Adventure Among Scientists MÓNICA M SOLÓRZANO KRAEMER - XAVIER DELCL ÓS ENRIQUE PEÑALVER. ANA RODRIGO

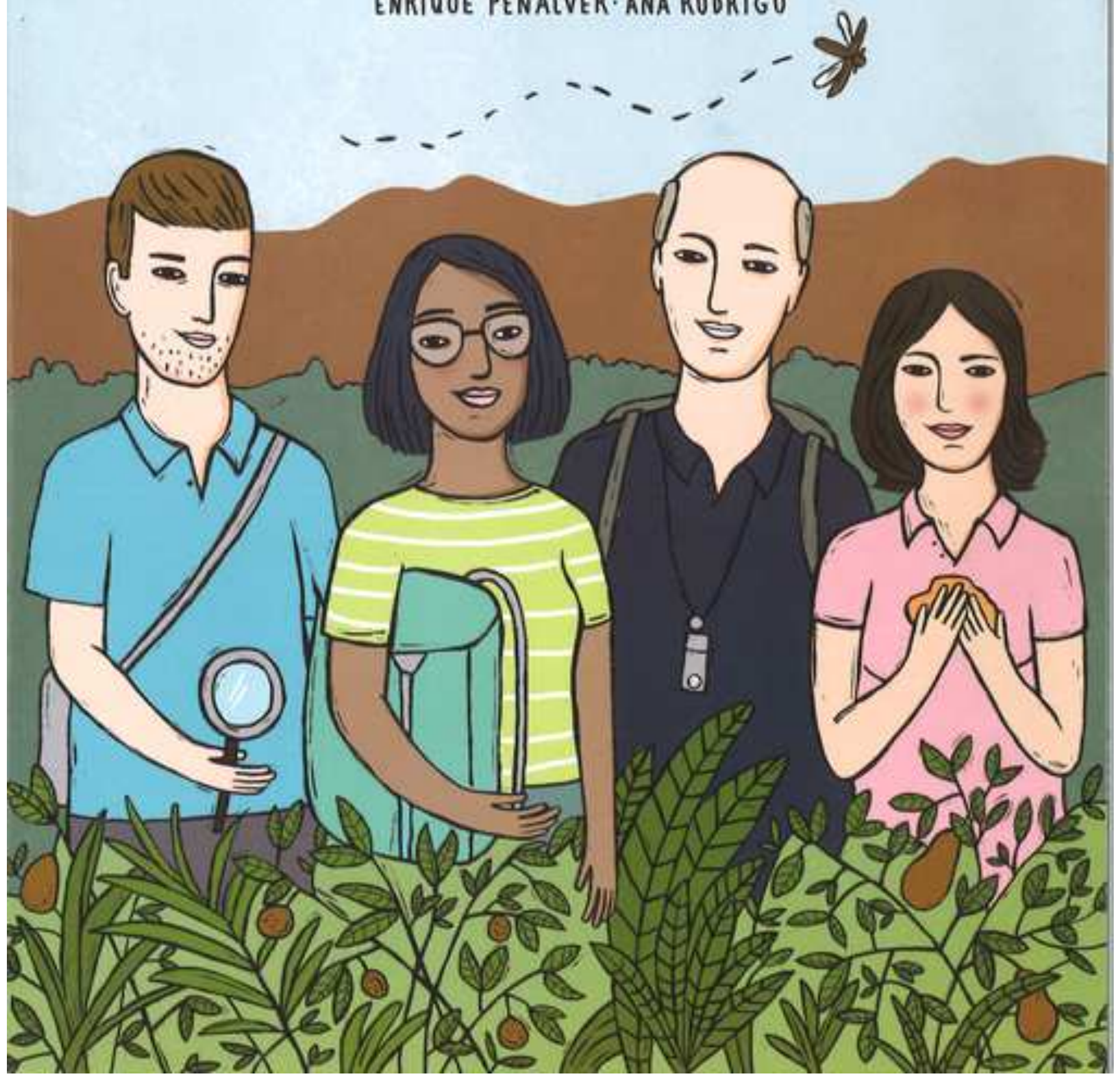

